\title{
KARAKTERISASI PEMBUATAN EDIBLE FILM DENGAN VARIABEL KOMBINASI TEPUNG KONJAK DAN KARAGENAN SERTA KONSENTRASI GLISEROL
}

\section{Characterization Of Edible Film Synthesis With Combination Variables Of Konjak Flour, Carrageenan And Glicerol Concentration}

\author{
Irman Ansari Adlin ${ }^{1}$, Yuliana Sebastiani ${ }^{2}$, Tifani Nur Hidayanti ${ }^{3}$ \\ 1,2,3 Prodi Teknik Kimia, Fakultas Teknik Universitas Pamulang, Banten \\ Jl.Surya Kencana No.1 Pamulang Barat Tangerang Selatan, Banten \\ Received : 11 Juli 2020; Accepted : 27 Juli 2020; Publish : Juli 2020
}

\begin{abstract}
ABSTRAK
Penggunaan plastik sebagai kemasan produk menyebabkan meningkatnya beban lingkungan karena sulit mendegradasikan plastic tersebut. Tuntutan untuk menjaga lingkungan menjadi pemicu melakukan penelitian untuk membuat substitusi plastic yang ramah lingkungan. Edible film dari bahan baku karagenan ( yang berasal dari rumput laut) menjadi salah satu alternative. Pada penelitian ini kami melakukan kombinasi karagenan dengan tepung konjak untuk mendapatkan karakteristik yang lebih baik. Tepung konjak merupakan tanaman iles iles (Amorphophallus) yang banyak mengandung umbi glukoman berupa heteropolisakarida yang terdiri dari $\beta$-Dglukosa $(\mathrm{G})$ dan $\beta$-D-manosa $(\mathrm{M})$ dengan rasio perbandingan 1:1,6. Tepung konjak dapat berfungsi sebagai bahan pengental, pembentuk gel, dan pengikat air. Tujuan pada penelitian ini yaitu untuk mengetahui kondisi karakteristik edible film dengan cara mengkombinasikan kandungan antara bahan dasar karagenan dengan tepung konjak dan mengvariasikan konsentrasi gliserol untuk mendapatkan tekstur jelly dan karaketristik yang lebih baik. Pada penelitian ini menggunakan 2 parameter yang divariasikan yaitu Kombinasi tepung konjak dan karagenan dengan perbandingan 1: 1, 1: 2 dan 1:3 dan konsentrasi gliserol yaitu $5 \%$, 10\% dan $15 \%$ dengan kondisi yang dikontrol yaitu temperature campuran $85^{\circ} \mathrm{C}$, Temperatur pengeringan $50{ }^{\circ} \mathrm{C}$ selama 24 jam. Penelitian ini menghasilkan data korelasi yaitu terhadap penambahan tepung konjak menyebabkan kadar air dan daya larut air meningkat serta laju perpindahan air menurun dan tidak berpengaruh pada ketebalan edible yang terbentuk. Sedangkan gliserol, semakin rendah konsentrasinya menyebabkan kadar air rendah, ketebalan edible film menurun, laju perpindahan air semakin naik, serta daya larutnya mengecil.
\end{abstract}

Kata kunci: Edible film, tepung konjak, karagenan, plasticizer

\section{PENDAHULUAN}

Edibel film merupakan lembaran dalam bentuk lapisan yang tipis yang kontak langsung dengan produk pangan yang aman dimakan bersamaan dengan produk pangan yang dikemasnya. Edible film ini terbuat dari hi- drokoloid, lipid, protein ataupun kombinasi dari ketiga item ini. Diantara bahan baku untuk pembuatan edible film ini yaitu karagenan yang dihasilkan dari rumput laut yang merupakan salah satu jenis polisakarida banyak tersedia sebagian wilayah Indonesia.Karagenan mempunyai kelebihan yaitu dapat membentuk gel yang baik,elastis, dan 
dapat dikonsumsi. Polisakarida jenis lainnya yang bisa digunakan untuk membuat edible film yaitu glukomanan yang merupakan komponen dominan dari tepung konjak dan juga dapat melarutkan dietary fiber. Keunggulan dari tepung konjak sebagai bahan pembuat edible film yaitu dapat membentuk gel yang elastis,melindungi dari oksigen,karbondioksida, minyak dan menaikkan kesatuan struktur produk, stabil terhadap asam, serta tahan pada garam walaupun dalam konsentrasi yang tinggi. Kekurangan dari tepung konjak yaitu mempunyai sifat hidrofilik, larut dalam air, viskositasnya tinggi. Sebagai bahan pembentuk gel, tepung konjak mempunyai kemampuan yang khusus yaitu bisa membentuk gel reversible maupun irreversible pada kondisi berbeda. Gel reversible terbentuk jika tepung konjak dikombinasikan dengan hidrokoloid lainnya seperti karagenan, xanthan gum dan lain lain. Gel Irreversibel terbentuk jika gel dari konjak dalam kondisi basa.

Kombinasi tepung konjak dan karagenan dalam pembuatan jelly bisa menghasilkan tekstur yang lebih baik dari jelly yang terbentuk dari tepung karagenan. Berdasarkan kondisi sinergi tepung konjak dan karagenan inilah yang menjadi dasar penelitian untuk menghasilkan edible film dengan tekstur dan karakteristik yang lebih baik dari edible film yang terbuat hanya dari tepung karagenan.

\section{BAHAN DAN METODE}

Alat:

- Gelas Beaker - Magnetic Stirerr

- Hot Plate Strirer - Cawan Petri

- Oven - Corong kaca

- Kertas Saring - Alumunium foil

- Epoxy (lem) - Neraca (timbangan)

Bahan :

- Tepung Konjak - Tepung Karagenan
- Aquadest - Gliserol

Metode Penelitian :

1. Persiapan sample produk edible film

a. Pembuatan sample dari tepung karagenan

i. Larutkan karagenan $3 \%(\mathrm{~b} / \mathrm{v})$ dalam aquadest pada suhu $85^{\circ} \mathrm{C}$.

ii. Aduk dengan magnetic stirerr selama 20 menit dan jaga suhu larutan pada $85^{\circ} \mathrm{C}$

iii. Tambahkan gliserol. Dengan konsentrasi masing-masing 5\%, $10 \%$ dan $15 \%$ lalu diamkan selama 5 menit.

iv. Cetak dalam cawan petri dengan perbandingan $0.3 \mathrm{ml} / \mathrm{cm} 2$.

v. Diamkan pada suhu ruang selama 2 jam.

vi. Panaskan dalam oven $50{ }^{\circ} \mathrm{C}$ selama 24 jam

2. Pembuatan edible film dari sinergi tepung konjak dengan tepung karagenan.

i. Timbang campuran tepung konjak dan tepung karagenan menggunakan konsentrasi $3 \%(\mathrm{~b} / \mathrm{v})$ dengan perbandingan $50 \%: 50 \%, 25 \%: 75 \%$ dan $33 \%: 67 \%$.

ii. Larutkan campuran tepung dalam aquadest suhu $85^{\circ} \mathrm{C}$.

iii. Aduk dengan magnetic stirerr selama 20 menit dan jaga suhu larutan pad $85^{\mathrm{O}} \mathrm{C}$

iv. Tambahkan gliserol. Dengan konsentrasi masing-masing 5\%, 10\% dan $15 \%$ lalu diamkan selama 5 menit

v. Cetak dalam cawan petri dengan perbandingan $0.3 \frac{\mathrm{ml}}{\mathrm{cm} 2}$

vi. Diamkan di suhu ruang selama 2 jam

vii. Panaskan dalam oven $50^{\circ} \mathrm{C}$ selama 24 jam

\section{Analisa Pengujian Edible Film}

i. Uji Kadar Air

Pengujian kadar air dilakukan dengan menggunakan moisturemeter 
analyzer dengan menyiap semua sample produk edible film dari semua hasil penelitian. Rancangan produk test dibuat $\mathrm{n}$ sebanyak 3 kali. Sample yang sudah ada dimasukan ke alat moisture meter analyzer maka secara langsung data kadar air tersaji pada pada alat tersebut.

ii. Uji Ketebalan

Pengujian ketebalan dilakukan dengan menggunakan mikrometer digital. Siapkan sample dengan per item parameter sejumlah 3 kali.

iii. Uji Laju Perpindahan Air

Pengukuran laju perpindahan air dilakukan dengan memodifikasi metode cawan yang mengacu pada ASTM E 96- 95 . Gelas beaker $50 \mathrm{ml}$ yang telah dibersihkan sebelumnya diisi akuades sebanyak $30 \mathrm{ml}$. Alumunium foil yang digunakan untuk menutupi permukaan cawan. Lubang yang dibuat pada alumunium foil mencapai $10 \%$ dari luas cawan. Selanjutnya potongan film dilekatkan pada permukaan lubang menggunakan epoxy (lem). Lalu cawan dimasukkan ke dalam oven pada suhu 37 \pm 0.5 oC selama 5-6 jam dan diukur masa air yang hilang setiap jamnya. Perhitungan laju perpindahan air/jam menggunakan rumus sebagai berikut: $\mathrm{K}=($ Jumlah selisih berat cawan tiap $\mathrm{jam}) /$ waktu

iv. Uji Daya Larut

Sampel edible film dipotong dengan ukuran $3 \times 2 \mathrm{~cm} 2$. Sampel dengan kertas saring dikeringkan pada suhu $105^{\circ} \mathrm{C}$, selama 24 jam. Kertas saring dan sampel ditimbang secara terpisah, untuk menentukan berat awal sampel (W1). Sampel dimasukkan ke dalam tabung sentrifuse $50 \mathrm{ml}$ yang berisi $10 \mathrm{ml}$ akuades. Perendaman dilakukan selama 24 jam pa- da suhu kamar dan diaduk perlahanlahan secara periodik menggunakan shaker. Larutan disaring, kemudian kertas saring dan film yang tidak larut dikeringkan menggunakan oven pada suhu $105^{\circ} \mathrm{C}$ selama 4 jam, setelah itu sampel ditimbang (W2) untuk menentukan bahan kering yang tidak larut dalam air. Kelarutan dihitung menggunakan formula:

Kelarutan $(\%)=(\mathrm{W} 1-\mathrm{W} 2) / \mathrm{W} 1 \times 100 \%$

\section{HASIL DAN PEMBAHASAN Persiapan sample edible Film.}

Hasil karakteristik dari sample yang sample dibuat sesuai dengan urutan metode dan variable penelitian didapat data tersebut pada table 1.

Tabel 1. Karakteristik Edible film dari kom posisi bahan baku karegenan dan konjak

\begin{tabular}{|c|c|c|c|c|c|c|c|}
\hline & Komposisi & Bahan Bakl & Gliserol & Kadar Air & Ketetbala & Laju Transmismisi Lap air & Kelaritan \\
\hline & Karagenanan & Konjajk & $\begin{array}{c}\% \\
\text { Konsentraini }\end{array}$ & $(\%)$ & $(\mathrm{cm})$ & $\mathrm{K}\left(\mathrm{grl} / \mathrm{gm}, \mathrm{m}, \mathrm{m}^{\mathrm{l}}\right)$ & $(\%)$ \\
\hline & 100 & 0 & 5 & 16,77 & 0,01 & 0,0564 & 16.35 \\
\hline & 100 & 0 & 10 & 17,82. & 0,01 & 0,527 & 19,56 \\
\hline & 100 & 0 & 15 & 18,35 & 0,03 & 0,492 & 2236 \\
\hline & 50 & 50 & 5 & 17,62 & 0,01 & 0,414 & 17.50 \\
\hline & 50 & 50 & 10 & 18,70 & 0,02 & 0,0390 & 23.42 \\
\hline & 50 & 50 & 15 & 19,77 & 0,03 & $0,0,342$ & 31.60 \\
\hline & 67 & 33 & 5 & 17,31 & 0,01 & 0,0486 & 16.53 \\
\hline & 67 & 33 & 10 & 18,52 & $0,0,2$ & 0,432 & 21.55 \\
\hline & 67 & 33 & 15 & 19,25 & 0,03 & 0,0388 & 29.91 \\
\hline & 75 & 25 & 5 & 16,82 & 0,01 & 0,0617 & 14.59 \\
\hline & 75 & 25 & 10 & 17,94 & 0,02 & 0,076 & 18.91 \\
\hline & 75 & 25 & 15 & 18,65 & 0,03 & 0,0421 & 2577 \\
\hline
\end{tabular}


dengan perobahan konsentrasi gliserol

\section{Analisa pengujian kadar Air}

Pada edible film, kandungan air yang tinggi akan menyebabkan aktivitas mikroba meningkatkan sehingga produk edible film akan lebih cepat rusak dan waktu simpan menjadi lebih pendek karena produk lebih cepat mengalami pembusukan. Edibel film umumnya digunakan sebagai kemasan primer dan untuk itu diharapkan tidak menambahkan kandungan air kedalam produk. sehingga edible film yang dikehendaki memiliki kadar air yang rendah.

Pada pengujian ini berfungsi untuk mengetahui hubungan antara kandungan komposisi bahan baku karagenan dan kombinasi karagenan dengan tepung konjak, dan besarnya pengaruh gliserol sebagai plasticizer terhadap kadar air produk. Data korelasi terlihat pada gambar 1 .

Gambar 1. Korelasi Komposisi bahan baku dan konsentrasi gliserol terhadap kadar air edible film

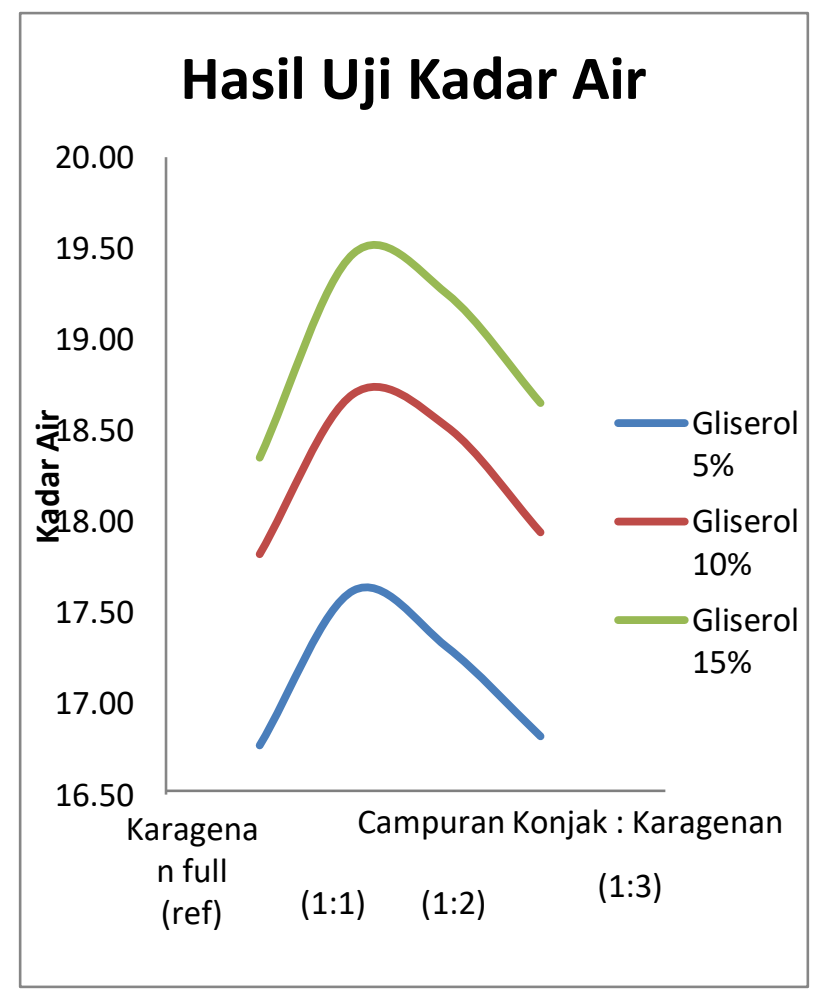

Jurnal IImiah Teknik Kimia
Hasil yang diperoleh dari uji uji kadar air ini menunjukkan bahwa semakin banyak kandungan konjak pada kombinasi bahan baku menyebabkan kadar air meningkat, dan sebaliknya karagenan semakin banyak kandungannya pada bahan baku akan menurunkan kadar air produk edible film ini. Untuk kandungan gliserol, semakin besar konsentrasinya maka semakin besar kadar air yang diperoleh. Hal ini dapat dilihat dari perbandingan variasi gliserol dengan komposisi yang sama pada bahan baku baik karagenan murni maupun kombinasi karagenan dengan tepung konjak.. Hal ini disebabkan gliserol bersifat hidrofilik sehingga mengikat air semakin besar Berdasarkan kondisi penelitian ini maka kondisi yang optimum yaitu kombinasi tepung karagenan dan kandungan tepung konjak dengan perbandingan 1:3 menghasilkan kadar air mendekati dengan kandungan karagenan dan konsentrasi gliserol 5\% menghasilkan kadar air terendah yaitu 16,82. Namun secara keseluruhan interval kadar air pada penelitian berkisar 16,82 hingga 19,47. Berdasarkan pendapat Martins et al. (2012) dan Kammani dan Rhim (2014), kadar air untuk berbahan dasar karagenan yaitu 19,28 dan 16,43. Berdasarkan pendapat ini maka kadar air film dari campuran konjak - karagenan masih masih bisa digunakan pada pengemasan produk pangan.

\section{Analisa pengujian Ketebalan Produk}

Karakteristik penting lainnya untuk menentukan kelaikan edible film yang dihasilkan yaitu Ketebalan. Ketebalan film akan memberikan proteksi yang baik pada produk yang dikemas. Selain itu ketebalan juga mempengaruhi sifat fisik dan mekanik dari produk edible film. Ketebalannya disesuaikan dengan jenis produk yang akan dikemas.

Pada pengujian ini berfungsi untuk mengetahui hubungan antara kandungan komposisi 
bahan baku karagenan dan kombinasi karagenan dengan tepung konjak, dan besarnya pengaruh gliserol sebagai plasticizer terhadap ketebalan produk edible film.. Data korelasi terlihat pada gambar 2 .

Gambar 2. Korelasi Komposisi bahan baku dan konsentrasi gliserol terhadap ketebalan edible film

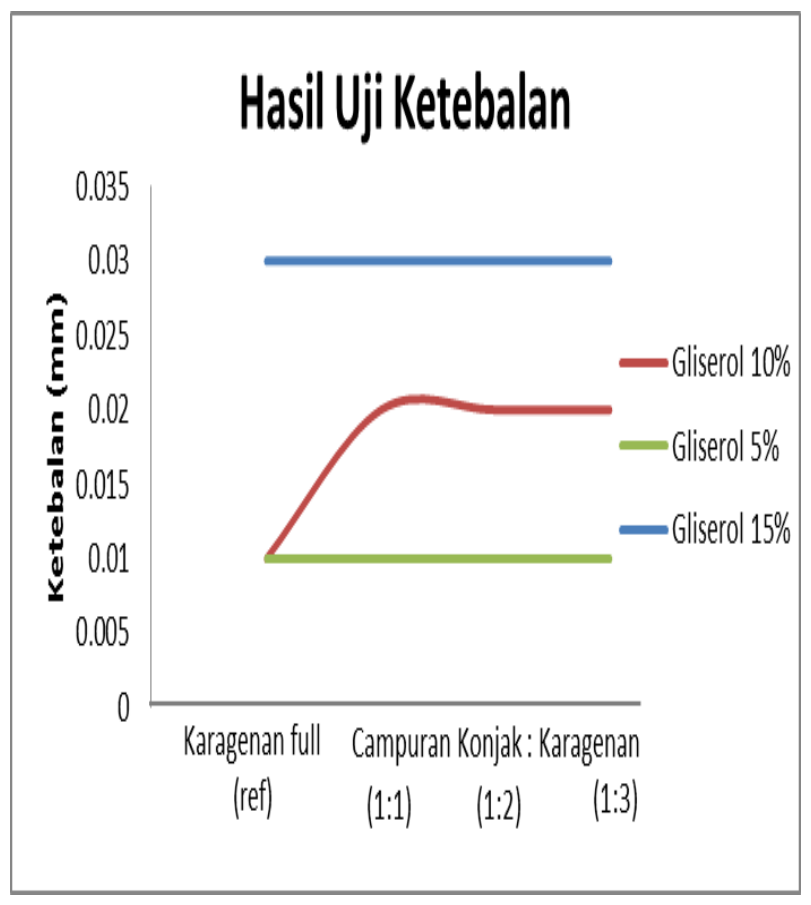

Hasil yang diperoleh dari uji ketebalan ini menunjukkan bahwa penambahan kandungan konjak pada kombinasi bahan baku tidak mempengaruhi ketebalan dari produk edible film. Sedangkan untuk konsentrasi gliserol memperlihatkan bahwa ketebalan produk sangat dipengaruhi konsentrasi gliserol sebagai plasticizer(pelapis). Semakin besar konsentrasi gliserol maka ketebalan produk semakin besar. Hal ini disebabkan fungsi pelapisan pada produk semakin besar dengan konsentrasi semakin besar. Gliserol mempengaruhi penyerapan air dan akibat proses swelling bisa menaikkan ketabalan pada batas tertentu.
Dari hasil penelitian ini, ketebalan film produk berkisar antara 0,01 $\mathrm{mm}-0,03 \mathrm{~mm}$. Berdasarkan standar dari JIS (Japan Industrial Standard) bahwa ketebalan edible film maksimum sebesar 0,250 mm. Menurut pendapat (Ariska dan Suyatni,2015) serta(Kusumawati,2013) bahwa ketebalan edible film untuk melapisi bahan pangan sesuai dengan jenis produk pangan tersebut.

\section{Analisa pengujian Laju Perpindahan Air}

Salah satu fungsi edible film adalah menahan migrasi uap air dengan maksud yaitu. menghindari uap air dalam produk hilang atau uap air dari luar produk terserap kedalam produk. Meningkatnya atau hilangnya uap air pada produk dapat mengakibatkan produk mudah rusak dan masa simpan produk lebih cepat. Berdasarkan hal tersebut maka laju perpindahan uap air merupakan salah satu parameter yang penting dalam menentukan kelayakan edible film sebagai kemasan.produk. Pada pengujian ini berfungsi untuk mengetahui hubungan antara kandungan komposisi bahan baku karagenan dan kombinasi karagenan dengan tepung konjak, dan besarnya pengaruh gliserol sebagai plasticizer terhadap laju perpindahan air pada produk edible film.. Data korelasi ini terlihat pada gambar 3.

Gambar 3. Korelasi Komposisi bahan baku

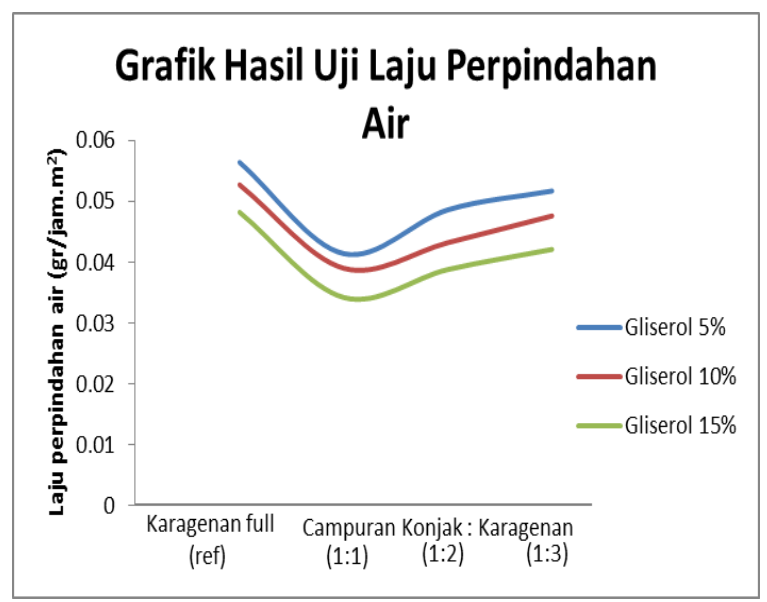


dan konsentrasi gliserol terhadap laju perpindahan uap air edible film

Hasil yang diperoleh dari uji laju perpindahan air ini menunjukkan bahwa semakin banyak kandungan tepung konjak pada campuran bahan baku edible film maka semakin kecil laju perpindahan air, dan sebaliknya semakin banyak kandungan karagenan semakin besar laju perpindahan air. Sedangkan untuk glaserol sebagai plasticizer, semakin besar konsentrasi gliserol maka laju perpindahan air semakin kecil. Hal ini disebabkan ikatan hydrogen dan membentuk pori yang lebih rapat sehingga laju transmisi uap air dapat berkurang. Berdasarkan hal tersebut maka kondisi yang ideal pada pembuatan edible film ini yaitu kandungan kojak besar (perbandingan 1:1 dengan karagenan) dan gliserol $15 \%$ menunjukkan laju perpindahan sebesar $0,0342 \mathrm{gr} / \mathrm{jam} . \mathrm{cm}^{2}$ sampai $0,0414 \mathrm{gr} / \mathrm{jam} . \mathrm{cm}^{2}$. Rendahnya laju perpindahan air pada film dengan bahan campuran konjak - karagenan terjadi karena efek sinergisme yang terjadi antara konjak dengan karagenan. Sinergisme yang terjadi membentuk struktur yang kompak dan padat sehingga meningkatkan kekuatan film dalam menahan uap air. Data dari hasil penelitian untuk laju perpindahan berkisar 0,0482 $\mathrm{gr} / \mathrm{jam} . \mathrm{cm}^{2}$ sampai $0,0564 \mathrm{gr} / \mathrm{jam} . \mathrm{cm}^{2}$.

\section{Analisa pengujian Kelarutan}

Parameter kelarutan film dalam air menunjukkan kemampuan film untuk larut dalam air dan juga menunjukkan kemampuan film dalam menahan air. Kelarutan yang tinggi dalam air membuat kemampuan menahan air berkurang. Kelarutan film tergantung kepada jenis produk yang dikemas. Film dengan daya larut yang tinggi cocok digunakan untuk produk pangan siap makan karena saat di konsumsi akan mudah larut. namun dalam beberapa produk pangan diharapkan film memiliki daya larut yang ren- dah karena film harus mamapu melindungi pangan dari uap air. Data korelasi ini terlihat pada gambar 4 .

Gambar 4. Korelasi Komposisi bahan baku dan konsentrasi gliserol terhadap Kelarutan edible film

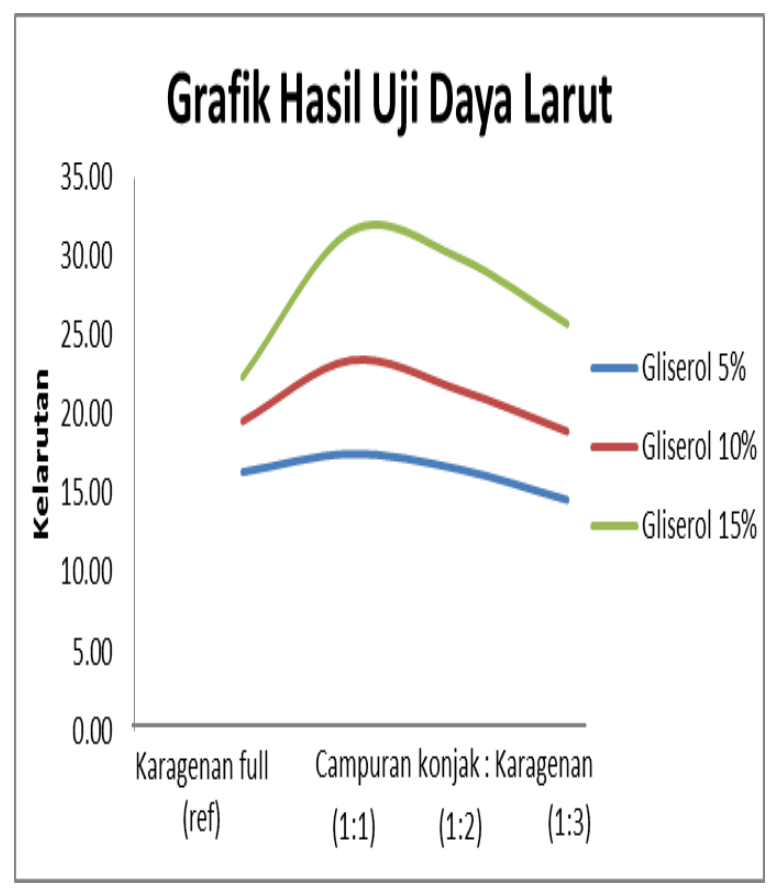

Hasil yang diperoleh dari uji kelarutan ini menunjukkan bahwa semakin besar kandungan tepung konjak menyebabkan kelarutan meningkatan,Hal ini disebabkan konjak memiliki sifat hidrofilik sehingga kelarutan semakin besar. Sedangkan untuk gliserol, semakin besar konsentrasi gliserol maka daya larut film senakin besar karena aktivitas interaksi antar molekul menurun.. Data hasil untuk kelarutan dari variable kombinasi tepung dan gliserol besarnya kelarutan berkisar : 14,5887 hingga 29,9880. Menurut Blanco Pascual, et al, film yaitu edible film dari bahan dasar protein memiliki kelarutan 40,75 sanpai dengan 29,908.Sedangkan menurut Bourbon et al. mengatakan bahwa edible film dengan bahan kitosan memiliki kelarutan 42,05 $47,11 \%$. Berdarkan hal tersebut, semua 
produk edibel film dari penelitiin lebih rendah dari hasil penelitian. Kondisi yang paling optimum yaitu pada kandungan kombinasi konjak dan karagenan 1:1, dengan gliserol $15 \%$.

\section{KESIMPULAN}

Berdasarkan hasil penelitian dan pembahasan pada bab sebelumnya dapat disimpulkan bahwa:

1. Penambahan tepung konjak pada bahan baku karagenan dalam membuat produk edible film menghasilkan korelasi terhadap karakteristik edible film sebagai berikut:

a. Laju perpindahan (transmisi) air semakin rendah.

b. Daya larut terhadap air meningkat

c. Tidak berpangaruh pada ketebalan produk edible film.

d. Kadar air edible film meningkat.

2. Dampak penambahan konsentrasi gliserol yang berfungsi sebagai plasticizer mendapat korelasi terhadap produk edi ble film yang dihasilkan yaitu:

a. Laju perpindahan (transmisi) air semakin rendah.

b. Daya larut terhadap air meningkat

c. Ketebalan produk edible film meningkat.

d. Kadar air edible film meningkat.

3. Hasil penelitian ini dengan perobahan variable berupa kombinasi bahan baku tepung konjak dan karagenan serta perobahan konsentrasi gliserol masih dalam karakteristik edible film jika menggunakan bahan baku karagenan saja.

\section{DAFTAR PUSTAKA}

[1] Arham,Metusalach,dkk. 2017.

Karakterisasi Edible Film Karagenan

Dengan Pemlastis Gliserol.JPHPI 2017,

Volume 20 Nomor 2. Retrieved from:

https://journal.ipb.ac.id/index.php/jphpi/artic le/viewFile/17499/12557.
[2] Adrianus O W Kaya,Ani Suryani,Joko Santoso,,dan Meika Syahbani Rusli,2014, Karakteristik dan Struktur Mikro Gel Campuran Semirefined Carrageenan dan Glukomanan,Jurnal Kimia dan Kemasan, Vol 37

No 1 April 2015.

[3] Aryanti,Nita dan Kharis Yohan Abidin. 2015. Ekstraksi Glukomanan Dari Porang Lokal. METANA,Vol. 11 No. 01 Juli 2015,Hal.21-30. Retrieved from https://ejournal.undip.ac.id/index.php/metan a/article/.../9776

[4] Dakay, B.U. 2008. Developing Partnership Between The Phillipnes and Indonesia in The Seaweed Industry. Seaweed Industry Association of The Phillipines.

[5] Hadi, Slamet. (2011). Makalah Karagenan. Makalah

Http://www.kemenperin.go.id/artikel/13572/ Rumput-Laut-Dikembangkan diakses pada tanggal (13 Juli 2019)

[6] Meir H. 1967. Mannan and galactomannan advance in carbohydrate. Academic, New York.

Saini, Anggakasi. Potensi Konjac Flour Di Indonesia.Dikutip tanggal 05 Juli 2019 dari Suara Jakarta : http://suarajakarta.co/ekstra/jurnaliswarga/potensi-konjac-flour-di-indonesia/

[7] Saragih, Iva Ancewita, Fajar Restuhadi dan Evy Rossi. 2016. Kappa Karaginan Sebagai Bahan Dasar Pembuatan Edible Film Dengan Penambahan Pati Jagung (Maizena). Jurnal Online Mahasiswa Fakultas Pertanian Universitas Riau, vol. 3, no. 1, Feb. 2016, pp. 1-12.

[8] Bourtoom T, Review Article Edible film and Coating: Caracteristics and properties, International Food Research Journal, 15, 2008 
[9] Ariska RE, Suyatno,2015, Pengaruh konsentrasi karagenan terhadap sifat fisik dan mekanik edible film dari pati bonggol pisang dan karagenan dengan plasticizer Gliserol, Prosiding Seminar Nasional Kimia jurusan Kimia FMIPA Universitas Negeri Surabaya, Surabaya, Oktober 2015. 